\title{
Investigation of C-reactive Protein and D-dimer Findings in Patients with COVID-19
}

\section{COVID-19 Hastalarında C-reaktif Protein ve D-dimer Bulgularının İncelenmesi}

iD Hayrullah YAZAR¹, id Yıldırım KAYACAN², io Mehmet ÖZDİN33

1Sakarya University Faculty of Medicine, Department of Medical Biochemistry, Sakarya, Turkey

${ }^{2}$ Yaşar Doğu Sports Science Faculty, Coaching Training, Samsun, Turkey

3 Sakarya Training and Research Hospital, Clinic of Biochemistry, Sakarya, Turkey

\section{ABSTRACT}

Objective: The purpose of this study is to examine the levels of C-reactive protein (CRP) and D-dimer by age and gender in the pandemic caused by the new coronavirus.

Methods: Coronavirus disease-19 (COVID-19) diagnoses were made according to the results of real-time polymerase chain reaction and lung computed tomography $(n=70)$. In the study, $\mathrm{CRP}$ and coagulation were examined as indicators of inflammation, and D-dimer was examined as an indicator of fibrinolytic system activity. Patients' age, gender, and CRP and D-dimer values were analyzed with Spearman's rho correlation, whereas the gender factor was analyzed with the Mann-Whitney $U$ test.

Results: Although D-dimer levels were high in women, there was no statistical significance. A correlation was identified between CRP and gender, and the levels in male patients were higher $(\mathrm{p}=0.049)$. A positive correlation was found between the patients' age and CRP and D-dimer findings.

Conclusion: There are two main findings in this study. First, age and gender are essential parameters in disease findings due to the COVID-19 pandemic. Their importance overlaps with the finding that inflammation is severe in elderly males and that the mortality is higher than in younger individuals. Second, the CRP and D-dimer test results can be used as practical and reliable biomarkers for COVID-19. We propose that if these two tests, which are already used routinely, are interpreted with consideration of age and gender, they can be used more efficiently in early diagnosis and isolation.

Keywords: SARS-Cov-2, COVID-19, C-reactive protein, D-dimer

\section{ÖZ}

Amaç: Bu çalışmanın amacı, yeni koronavirüsün neden olduğu pandemide ilk tanı konulduğu anda C-reaktif protein (CRP) ve $\mathrm{D}$-dimer düzeylerinin yaş ve cinsiyete göre incelenmesidir.

Yöntemler: Gerçek zamanlı polimeraz zincir reaksiyonu ve akciğer bilgisayarlı tomografi $(\mathrm{n}=70)$ sonuçlarına göre COVID-19 tanıları konuldu. CRP inflamasyonun göstergeleri olarak, D-dimer ise fibrinolitik sistem aktivitesinin bir göstergesi olarak incelendi. Hastaların yaşı, cinsiyeti, CRP ve D-dimer değerleri Spearman'ın rho korelasyonu ile analiz edilirken cinsiyet faktörü Mann-Whitney U testi ile analiz edildi.

Bulgular: Kadınlarda D-dimer düzeyleri yüksek bulundu, ancak istatistiksel olarak anlamlılık tespit edilmedi. Erkek hastalarda ise CRP düzeyleri anlamlı olarak yüksek bulundu $(\mathrm{p}=0,049)$. Hasta yaşı ile CRP ve D-dimer arasında pozitif korelasyon bulundu.

Sonuç: Çalışmada iki ana sonuç ortaya çıtı. Birincisi, yaş ve cinsiyetin COVID-19 salgını nedeniyle gerçekleşen hastalıkta önemli bir parametre olduğudur. Bu bulgu, yaşlı erkeklerde inflamasyonun şiddetli olduğu ve gençlere göre ölüm oranının daha yüksek olması bulgusuyla örtüşmektedir. İkinci sonuç ise, CRP ve D-dimer testlerinin COVID-19 için pratik ve güvenilir bir belirteç olabileceğidir. Zaten rutin olarak kullanılan bu iki testin yaş ve cinsiyet dikkate alınarak yorumlanması halinde erken teşhis ve izolasyonda daha verimli kullanılabileceğini öneriyoruz.

Anahtar Sözcükler: SARS-Cov-2, COVID-19, C-reaktif protein, D-dimer

Cite this article as: Yazar H, Kayacan Y, Özdin M. Investigation of C-reactive Protein and D-dimer Findings in Patients with COVID-19. Bezmialem Science. 2021;9(Supplement 1):4-8. 


\section{Introduction}

New coronavirus disease (COVID-2019) was first seen in the city of Wuhan in Hubei State in China. According to the World Health Organization, a single-stranded RNA virus, named SARS$\mathrm{CoV}-2$, was identified as a pathogen in patients with unexplained pneumonia since December 2019 (1). This pandemic spread worldwide in a short amount of time. A study showed that the new coronavirus infects humans through an incubation period of 1-14 days (2). It was stated that the new coronavirus infections could trigger not only respiratory tract diseases but also inflammation, high fever, cough, acute respiratory tract infection, and dysfunction of internal organs leading to death. The new coronavirus is first attacked by mast cells found in the submucosa of the respiratory tract and nasal cavity that act as a protective barrier against microorganisms (2). In the early stages of COVID-19, the benefits of C-reactive protein (CRP) level measurements were revealed in a study. In the study, lung lesions and CRP levels were associated. A positive correlation was found between the diameter of lung lesions and CRP levels. Since there is no treatment for COVID-19 disease, research on biomarkers has been brought to the forefront (3). CRP and D-dimer were the prominent ones in the search for biomarkers. (CRP), which is referred to as an acute-phase reactant (APR), was first discovered in the sera of pneumococcal pneumonia patients (4). The increase of APR concentration due to inflammation and tissue damage was identified in the serum level $(5,6)$. Undoubtedly, the increase of CRP in the serum a few hours after the inflammation led to it being one of the first biomarkers considered in COVID-19.

Another biomarker associated with COVID-19 sepsis is D-dimer, which is a product resulting from D-dimerfibrin destruction. It is the smallest protein fragment identified in blood when a blood clot is degraded (fibrinolysis). Its name derives from the two cross-linked D fragments of fibrin protein. D-dimer is a reliable test and has been preferred for patients with a suspected clotting disorder since the 1990s (7). D-dimer measurements and monitoring gained importance with the occurrence of sepsisinduced coagulopathy in COVID-19 patients. Some clinicians eliminated this situation by using heparin to reduce the risk of the spread of intravascular clotting and venous thromboembolism (8). In our study, we investigated whether there was a relationship between CRP, D-dimer, and COVID-19. In addition, we considered age and gender factors. Our literature search showed that no other study had evaluated these four parameters at the same time. Our study will contribute to the more efficient use of CRP and D-dimer tests that are widely and routinely used in all healthcare institutions and will accelerate the process, enabling the early diagnosis of COVID-19.

\section{Method}

The patients' information on gender and age were obtained from the Hospital Information Management System. The diagnoses of all the patients included in the study with COVID-19 were made based on the results of a real-time polymerase chain reaction and lung computed tomography. Twenty-four patients were admitted to emergency rooms, whereas 41 patients were admitted to the infectious disease department, and five were admitted to pediatric polyclinics ( $n=53$ males and $n=17$ females). The mean ages of patients were $55.11 \pm 2.92$ for males and 55.18 $\pm 5.80( \pm$ SEM) for females. Patient samples were collected by phlebotomists from venous blood. Biochemical tests were performed in the emergency labs using plasma samples for D-dimer and serum for CRP.

\section{Statistical Analysis}

For analyzing the data, SPSS v.21 (IBM, USA) was used. The patient findings did not show a normal distribution (ShapiroWilk test, $\mathrm{p}=0.000$ ), so Spearman's rho was used for correlation analyses, whereas the Mann-Whitney $U$ test was used to identify the differences between genders. A significance level of $\mathrm{p}<0.05$ was accepted. The study was approved by the Medical School Ethical Committee (ethical number: 050.01.04/106).

\section{Biochemical Analyses}

\section{CRP Latex}

Cold centrifuge procedures were performed at 5,000 rpm for 10 minutes to obtain serum. The device used in the study was a Beckman Coulter AU5800 Clinical Chemistry Fully Automatic System (The Fastest AU Analyzer Ever. Serial Number: 2016022598. Tokyo/Japonya). The accepted normal range for CRP was $0.00-5.00 \mathrm{mg} / \mathrm{L}$.

Collinearity: The test was collinear in the concentration range of $0.2-480 \mathrm{mg} / \mathrm{L}$ for a normal application and the concentration range of $0.08-80 \mathrm{mg} / \mathrm{L}$ for a very sensitive application.

Sensitivity: The lowest levels that could be identified were 0.20 $\mathrm{mg} / \mathrm{L}$ for normal and $0.05 \mathrm{mg} / \mathrm{L}$ for very sensitive. The lowest level that could be identified represents the lowest CRP level measured and distinguished from zero. The standard deviation was calculated as the absolute mean of 20 repetitions of a sample that does not contain analytes plus three.

Accuracy: Accuracy was obtained using three serum pools analyzed over 20 days for CRP (Latex) normal and high-level sensitive tests. The cofficient of variation $\%$ value in the study was found to be very sensitive, with a total of 3.48 .

\section{D-dimer}

Measurements were performed using the fragmental improved immunoturbidimetric test. Normal values for D-dimer were accepted as 0-500 $\mu \mathrm{g} \mathrm{FEU/mL.} \mathrm{A} \mathrm{D-dimer} \mathrm{test} \mathrm{was} \mathrm{performed}$ using venous blood plasma. Plasma was obtained after centrifuging for 20 minutes at $3200 \mathrm{rpm}$ and then run on the Diagon Coag XL (SN: 30115-03082015), which was followed by $\mathrm{D}$-dimer measurements. All patient samples were run with the same lot numbers in the same Diagon XL coagulation device.

Measuring range: The test was developed to identify D-dimer concentrations between the measurement range of 0.22-8.0 $\mu \mathrm{gFEU} / \mathrm{mL}$. When the values were above this range, the samples were diluted. 
Specificity: Dia-D-dimer is an immunological test unique for human D-dimer because of its antibodies. No interaction with rheumatoid factor up to $50 \mathrm{IU} / \mathrm{mL}$ was observed.

Cut-off value: The lowest identification threshold is $0.22 \mu \mathrm{g}$ $\mathrm{FEU} / \mathrm{mL}$.

\section{Results}

The descriptive statistical findings for CRP (mg/L), D-dimer $(\mu \mathrm{gFEU} / \mathrm{mL})$, age (years), and gender are presented in Table 1. When differences were examined based on gender (MannWhitney $\mathrm{U}$ test), it was found that the CRP level was higher diagnosis. Our study emphasizes that using easy and practical tests for routine use by developing an algorithm for pre-diagnosis would result in a more successful fight against the virus in many countries.

In this study, we found that advanced age was effective in the prognosis of this disease. There is a limited number of studies in the literature because this virus is novel. Saghazadeh and Rezaei (18) found that the older population has a higher risk of catching COVID-19. In our study, $47.8 \%$ of the patients admitted to our hospital were in the 60 and older age group. Tolia et al. (9) reported that most patients they received and diagnosed with COVID-19 were males.

Table 1. Descriptive statistics and Mann-Whitney U findings of the parameters

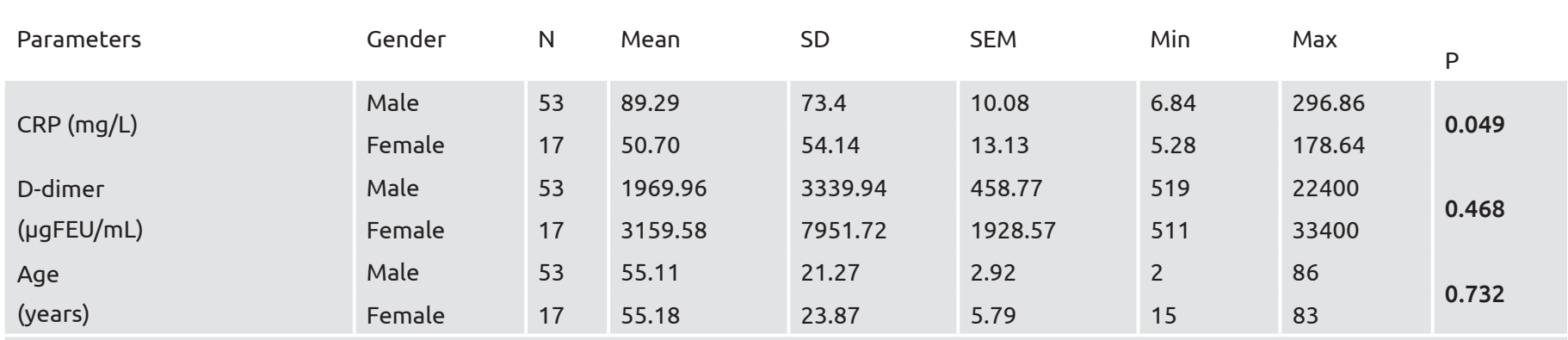

There are descriptive statistical findings according to the gender of the patients. It is seen in the table that the average age is very close in the two genders. CRP findings were detected at a high level in men and D-dimer in women. It was determined that CRP value was significantly higher in male patients.

SD: Standard deviation, CRP: C-reactive protein, Min: Minimum, Max: Maximum

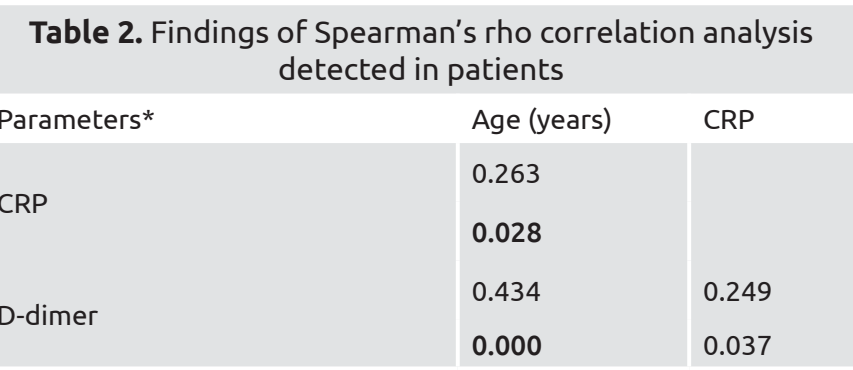

According to the analysis, a positive correlation was found among age, CRP and D-dimer findings. In other words, it is seen that these data increase as age increases. Also, there was a correlation between CRP and D-dimer. (*: The top line shows the $r$ values and the bold numbers indicate the $p$ values.) CRP: C-reactive protein

in male patients than female patients $(\mathrm{p}<0.05$; Table 2$)$. A positive correlation was identified between patient age and CRP $(\mathrm{p}=0.000)$ and $\mathrm{D}$-dimer $(\mathrm{p}=0.028)$. It was observed that as age increases, both CRP and D-dimer findings increase.

\section{Discussion}

On March 10, 2020, the World Health Organization declared a global pandemic because of the widespread infection of the COVID-19. The first COVID-19 case in Turkey was seen on March 11, 2020. The late start compared with other countries was considered as a pleasant development. However, the speed at which the virus spread, particularly in the young population, was remarkable. Germany and South Korea are considered as the countries that fight COVID-19 the best because of early

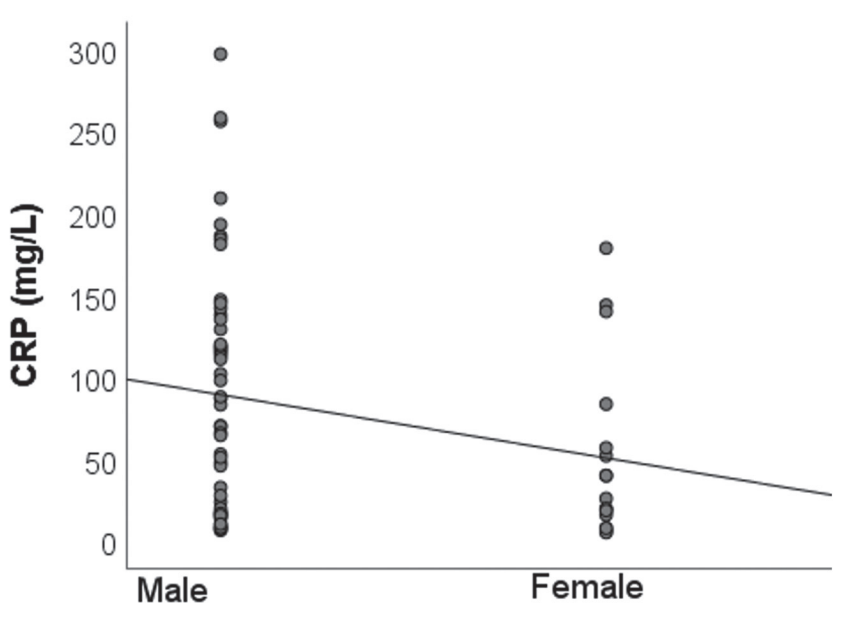

Figure 1. The comparison of the CRP by gender CRP findings were found as $89.29 \pm 10.08$ in men and $50.7 \pm 13.13$ (SEM) in women. This value was found to be significantly higher in men with COVID-19 CRP: C-reactive protein, COVID-19: Coronavirus disease-19, SEM: Scanning electron microscope

Similarly, it was significant that 53 of the diagnosed patients with COVID-19 were males in this study (9). In a study conducted with 140 COVID-19 patients in China, the distribution of the two genders was found to be equal. In contrast, another study conducted on critical patients showed that women were affected by COVID-19 67\% more than men (10). A recent report 

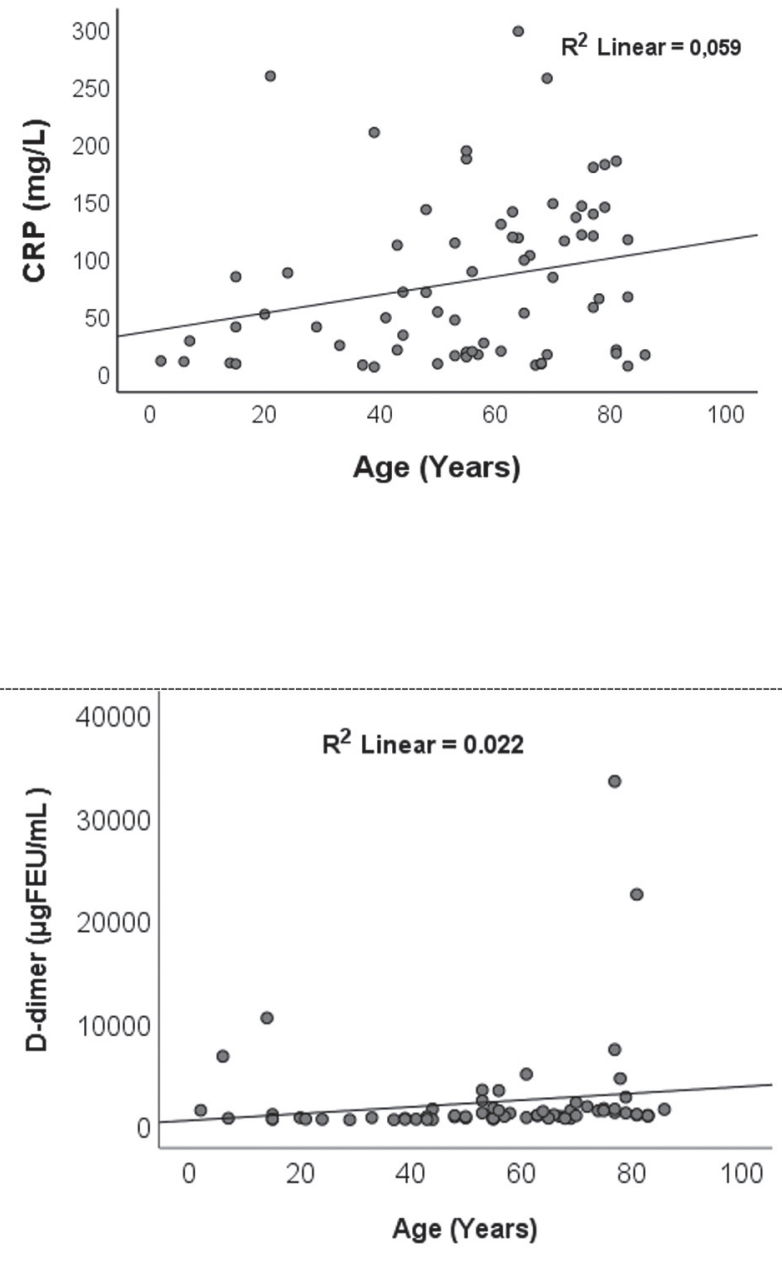

\section{D) Correlation graph determined} between CRP 9nda ge

It can be seen that the CRP values detected in patients are higher than 60 years of age. There was a significant relationship between age and CRP $\left(\mathrm{R}^{2}=\right.$ $0.059)$

\section{B) Correlation graph determined}

\section{between D-dimer 9nda ge}

D-dimer data is observed to be significantly concentrated in patients aged 60 and over $\left(\mathrm{R}^{2}=0.022\right)$.

Figure 2. Correlations of CRP and D-dimer with age (years) CRP: C-reactive protein

stated that $58 \%$ of the 1,099 patients with COVID-19 in 552 hospitals in 30 cities in China were males (11). These data show that COVID-19 may show gender tendency and that men are more prone to be affected. This gender tendency may be due to men's high levels of smoking compared with women in China (in 2018, the number of smokers was 288 million for men and 12.6 million for women). In the current study, we could not obtain data on patients' smoking habits, but we believe that smoking may be a factor in the density of the male population.

In the current study, we examined the CRP and D-dimer parameters by gender and age. No other studies in the literature with the patient population of our study examines gender/age factors. Mi et al. (12) examined CRP and D-dimer values in patients in their 40s who were diagnosed with COVID-19. Their findings showed high levels of CRP and D-dimer in all patients (12). Similarly, Chen et al. (13) found that CRP and D-dimer values were high in their study, consisting of 21 (17 male and four female) patients diagnosed with COVID-19. The low number of patients in these two studies prevents making a general evaluation. Our study, which consists of more patients with COVID-19, supports the high levels of C-reactive and D-dimer in COVID-19 patients. According to the findings of a study conducted by Wang (3), CRP may positively correlate with lung lesions in the early diagnosis of COVID-19 and reflect the severity of the disease. In addition to the similar findings we obtained in our study, a relationship between an increase in CRP mainly and gender and age was found. Tang et al. (14) evaluated the $\mathrm{D}$-dimer test parameter in identifying low molecule weight heparin effectiveness in their study. Their results showed that the 28-day mortality of heparin users was lower than those who did not use heparin. They also found high D-dimer levels in COVID-19 patients. However, in our study, we evaluated CRP and D-dimer together. Yu and Yang (15) conducted a study on COVID-19 cases and found that a significant number in society continue to live asymptomatically. According to them, this puts the whole society at risk. The data in our study clearly showed the relationship between CRP and D-dimer tests and COVID-19. 
If the two tests used in our study are used for screening purposes, it is possible to identify cases early. Furthermore, the examination of four parameters simultaneously is unique. Not having easy access to COVID-19 tests and definitive diagnosis kits being time-consuming leads to the question, "Can a new algorithm be developed by evaluating CRP, D-dimer, age, and gender?" CRP and D-dimer tests are practical tests being used routinely in all healthcare institutions. Evaluation of these two tests with age and gender can accelerate the path to early diagnosis of the disease and contribute positively to the fight against COVID-19.

\section{Conclusion}

A relationship between the COVID-19 pandemic due to new coronavirus and age and gender was found. Particularly in elderly male patients, it is possible to use CRP and D-dimer monitoring as biomarkers of inflammation. The low mortality rate in those with high disease resistance highlights the need to examine patients' lifestyles who are affected by this disease. Germany and South Korea are the two countries that receive attention for their successful handling of COVID-19. Since these two countries are test manufacturers led to the early diagnosis and isolation of more people. The speed of disease spread was significantly below the world average. Other countries may not have tests that provide comprehensive and fast results for a confirmed diagnosis of COVID-19. However, they have CRP and D-dimer options that are easily accessible, practical, and routinely used. We recommend developing a new algorithm for testing CRP and D-dimer in individuals regardless of age and gender. People with high results on the test would be isolated fast as "suspected cases" to reduce the spreading speed of COVID-19.

\section{Ethics}

Ethics Committee Approval: The study was approved by the Medical School Ethical Committee (ethical number: 050.01.04/106).

Informed Consent: Retrospective study.

Peer-review: Externally peer reviewed.

\section{Authorship Contributions}

Concept: H.Y., Design: H.Y., Data Collection or Processing: M.Ö., Analysis or Interpretation: H.Y., M.Ö., Y.K., Literature Search: Y.K., Writing: H.Y., Y.K., M.Ö.

Conflict of Interest: No conflict of interest was declared by the authors.

Financial Disclosure: This work was supported by Gilead Sciences.

\section{References}

1. Li Y, Guo F, Cao Y, Li L, Guo Y. Insight into COVID-2019 for pediatricians. Pediatr Pulmonol 2020;55:1-4.

2. Kritas SK, Ronconi G, Caraffa A, Gallenga CE, Ross R, Conti P. Mast cells contribute to coronavirus-induced inflammation: new anti-inflammatory strategy. J Biol Regul Homeost Agents 2020;34:914.

3. Wang L. C-reactive protein levels in the early stage of COVID-19. Med Mal Infect 2020;50:332-4.

4. Kushner I, Samols D. Oswald Avery and the pneumococcus. Pharos Alpha Omega Alpha Honor Med Soc 2011;74:14-8.

5. Kushner I. The phenomenon of the acute phase response. Ann N Y Acad Sci 1982;389:39-48.

6. Gabay C, Kushner I. Acute-phase proteins and other systemic responses to inflammation. N Engl J Med 1999;340:448-54.

7. Yazar H, Özdemir F, Köse E. Effect of centrifuge temperature on routine coagulation tests. Acta Haematol 2018;139:158-63.

8. Saghazadeh A, Rezaei N. Immune-epidemiological parameters of the novel coronavirus - a perspective. Expert Rev Clin Immunol 2020;16:465-70.

9. Tolia VM, Chan TC, Castillo EM. Preliminary results of initial testing for coronavirus (COVID-19) in the emergency department. West J Emerg Med 2020;21:503-6.

10. Zhang JJ, Dong X, Cao YY, Yuan YD, Yang YB, Yan YQ, et al. Clinical characteristics of 140 patients infected with SARS-CoV-2 in Wuhan, China. Allergy 2020;75:1730-41.

11. Guan WJ, Ni ZY, Hu Y, Liang WH, Ou CQ, He JX, et al. Clinical characteristics of coronavirus disease 2019 in China. N Engl J Med 2020;382:1708-20.

12. Mi B, Chen L, Xiong Y, Xue H, Zhou W, Liu G. Characteristics and early prognosis of COVID-19 infection in fracture patients. J Bone Joint Surg Am 2020;102:750-8.

13. Chen G, Wu D, Guo W, Cao Y, Huang D, Wang H, et al. Clinical and immunological features of severe and moderate coronavirus disease 2019. J Clin Invest 2020;130:2620-9.

14. Tang N, Bai H, Chen X, Gong J, Li D, Sun Z. Anticoagulant treatment is associated with decreased mortality in severe coronavirus disease 2019 patients with coagulopathy. J Thromb Haemost 2020;18:1094-9.

15. Yu X, Yang R. COVID-19 transmission through asymptomatic carriers is a challenge to containment. Influenza Other Respir Viruses 2020;14:474-5. 